\title{
Contradiction and Consensus in American Urbanism
}

\author{
Emily Talen \\ Professor, School of Geographical Sciences and Urban Planning, Arizona State University
}

doi:10.5618/arch.v2.3 || Received: 2012-01-06, Accepted: 2013-02-08, Available online: 2013-02-13

\begin{abstract}
New Urbanism can be thought of as a movement that attempts to reconcile principles of diversity, connectivity, equity, and human scale - i.e., principles of "good" urbanism - that have been evolving in America for over a century. Another way to frame the definition of "good urbanism" is by way of contrast with modernist urbanism. To present that perspective, a case must be made that modernist urbanism is distinct from all other forms of $\mathbf{2 0}^{\text {th }}$ century urbanism, something that Jane Jacobs, for one, was unwilling to do. This paper discusses the broader, dual conceptions of urbanism and looks at how they played out during the $20^{\text {th }}$ century. My intent is not to rehash a history that is already well known, but to highlight the elements in this evolution that have contributed to a more explicit and enlightened definition of what good urbanism at the beginning of the $21^{\text {st }}$ century is supposed to be.
\end{abstract}

Keywords: New Urbanism, modernist urbanism, diversity, equity

\section{Introduction}

If urbanism is defined as the created human habitat, urbanism can be evaluated normatively - good distinguished from bad. As conceptualized in the $21^{\text {st }}$ century, good urbanism is guided by principles of diversity, connectivity, equity, human scale, and a wellcared for public realm. Its antithesis - what might be termed "bad urbanism" - can be defined using similar terms: separation, segregation, lack of human scale, and the neglect of the public realm. After a century or more of wrestling with these definitions, good vs. bad urbanism are now largely definable concepts.

It has taken more than a century to sort this out. Elsewhere I have argued that what has now emerged as the American brand of urbanism is a mix of four "cultures" that have been evolving since the $19^{\text {th }}$ century - incrementalism, plan-making, regionalism, and planned communities. ${ }^{1}$ I argued that these ideals overlap in their adherence to the essential qualities of good urbanism (diversity, connectivity, public space, equity, place), and that principles are articulated at different levels of intensity, involving different ideas about order. I presented a case that New Urbanism is attempting to reconcile these divergent takes on urbanism that have been evolving in America for over a century.

But there is another way to frame the evolution of urbanism. If modernist urbanism is brought into the fold, the similarities of the four cultures of urbanism become more pronounced than their differences. Modernist urbanism presents the counterposition, making our ability to define good vs. bad urbanism that much clearer. To present that perspective, however, a case must be made that modernist urbanism is distinct from all other forms of $20^{\text {th }}$ century urbanism, something that Jane Jacobs, for one, was unwilling to do.

This paper discusses the broader, dual conceptions of urbanism and looks at how they played out during the $20^{\text {th }}$ century, especially in the first several decades. Broadly, urbanistic ideals begun in the early $20^{\text {th }}$ century - initially corresponding with Progressive Era reforms mingled with modernist urbanism of the 1920s to eventually spark a backlash that defines what we now think of as good urbanism. This interplay - between Progressive Era ideas about urbanism and modernist ideas espoused by the Congrès International d'Architecture Moderne (CIAM) (or International Congress of Modern Architecture) - is an interesting story. ${ }^{2}$ My intent is not to rehash a history that is already well known, but to highlight the elements in this evolution that have contributed to a more explicit and enlightened definition of what good urbanism at the beginning of the $21^{\text {st }}$ century is supposed to be.

One reason it is important to understand the differences is that, on the level of stated principle, Progressive Era planners and CIAM modernists overlap significantly. Jane Jacobs certainly lumped them 


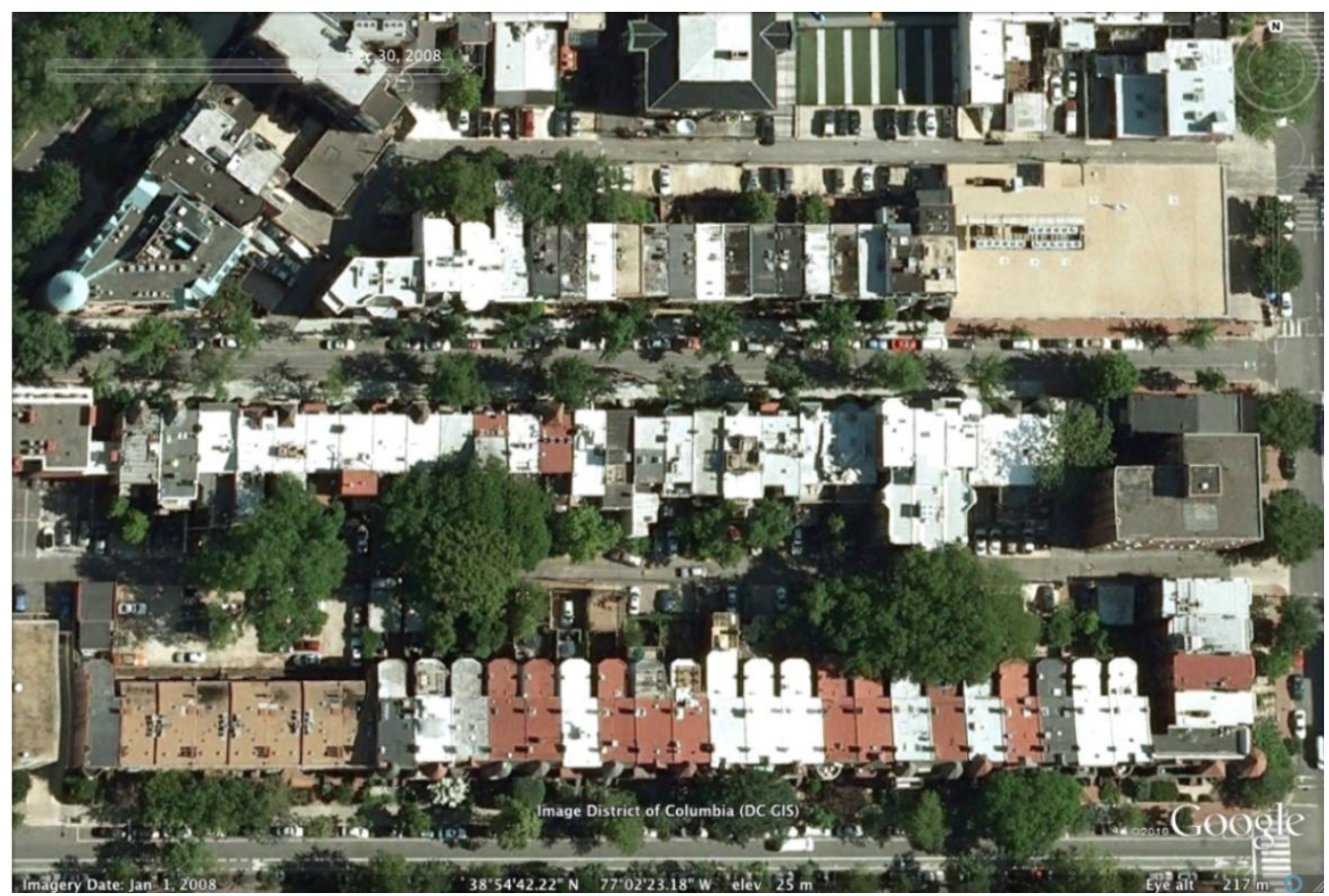

Fig 1. Traditional urban form, with its small blocks and diverse building types, such as this part of Washington, D.C, can be contrasted with modernist urbanism. Source: Google Earth.

together into one monolithic group of anti-urbanists. It is true that in terms of ideals, there are similarities. Modernists advocated the equitable distribution of wealth, utopian, future-oriented plan-making, affordable housing, efficiency in production methods, collectivism, and the need to situate places of work within reasonable distance of places of residence. A set of resolutions crafted by CIAM in 1933 included statements like "the city should assure individual liberty and the benefits of collective action," that "all urban arrangements should be based on the human scale," and that "urbanism should determine the relationships between places...according to the rhythm of everyday activity of the inhabitants." ${ }^{3}$ Sigried Giedion stated unequivocally that what was most important to CIAM was "planning from a human point of view."

On the ground, of course, the modernists were proposing a fundamentally different idea about urbanism than anyone aligned with Garden Cities, City Beautiful, City Efficient, or regionalism in the early $20^{\text {th }}$ century would have allowed. Contrasting the competing and at times overlapping approaches to urbanism that evolved out of the early $20^{\text {th }}$ century shows that our current, $21^{\text {st }}$ century notion of good urbanism has much in common with the earlier group of urbanists, even though this group was overshadowed and to some degree taken in by modernist urbanism. But it also shows that our current understanding of what constitutes good urbanism emerged out of the interaction between them.

\section{Parallels and contradictions: two conceptions of urbanism}

Idealized notions of what constitutes good urbanism in an American context solidified in the beginning of the 20th century following decades of experimentation. The response to the 19th century industrial city had been many and varied: utopian communities, civic improvement, municipal art, Garden Cities, the City Beautiful, regionalism. Visionaries and writers, religious leaders, philanthropists, politicians, industrialists, architects, and urban dwellers pushed new ideas to improve the human condition and the physical environment. Some were utopian and escapist, some were incremental, and some expressed grandeur. Some were religiously motivated and many sought social and moral redemption. There was a perception that the industrial city rested on an unjust social structure, and that reform required a new form of city. ${ }^{5}$ 


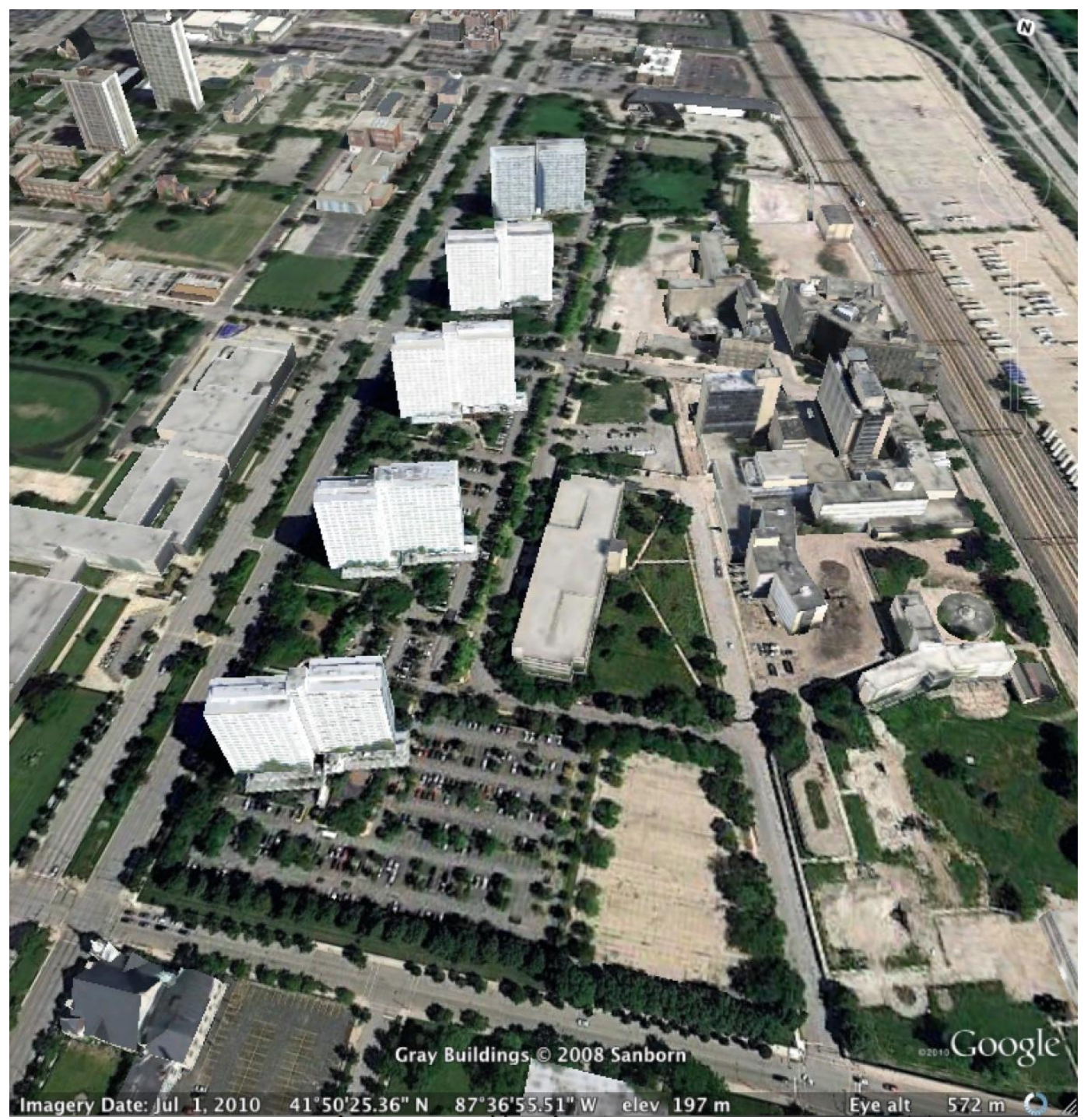

Fig 2. Modernist urbanism is exemplified in the Prairie Shores development on the south side of Chicago. Source: Google Earth.

Early motivations to heal the $19^{\text {th }}$ century city were often cast in what Charles Jencks calls "eschatological and hysterical" terms, punctuated with "overtones of the hospital and operating theatre." The preoccupation with sterilizing, opening up, and sorting urban places in ways that made them more innocuous was reinforced by the City Beautiful movement (1899-1909). Insistence on the order and uniformity of classicism provided a framework not only for architecture, but for the city itself. Working within the requirements of "proportion, harmony, symmetry, and scale," the aesthetic principles of the City Beautiful were tied to earlier European
Baroque planning, which Jane Jacobs labeled a "retrogressive imitation Renaissance style.", The spatial order of buildings and streets was highly regularized, with grouped public buildings and radial streets terminating in monumental arrangements. Contrary to contemporary concepts of good urbanism, a geometric order was imposed on the finer-grain grid of the existing urban fabric. 
Critics viewed the City Beautiful approach to urbanism as an attempt to gloss over the contradictions of capitalism: economic prosperity alongside social injustice and poverty. The 1909 Plan of Chicago, the quintessential City Beautiful plan, was condemned as seeking to procure "essentially an aristocratic city [for] merchant princes," 8 an exercise in "aesthetic megalomania"9 devoted to visual rather than humanitarian goals. City Beautiful urbanism included parks, playgrounds, and neighborhood centers, but housing was excluded, and practitioners failed to make the connection between degradation and the regulation of private development.

City Beautiful notions of urbanism evolved into what was believed to be a more "scientific" approach, the City Efficient. As it turned out, the City Beautiful and the City Efficient were not that different. While many appreciate the civic qualities embedded in both brands of urbanism, there was a significant, lingering downside: ordered, formalistic notions of urbanism tended to coincide with the separation of urban functions. It caused the city to lose its ability to function as an "organism" and suffer a loss that was both social and aesthetic. ${ }^{10}$ For Jane Jacobs, the issue was that such plans contradicted the functional and economic needs of cities. The tendency to break the urban environment into single components - parks, streets, highways - was, as one planner of the time put it, "a divide and conquer system." " Urbanism became scientific and efficient by simplifying, and simplifying meant differentiating.

This was exactly the point at which CIAM rose to prominence and took over the project of defining urbanism. Although the CIAM definition was essentially a continuation of longstanding ideas that had taken hold by the 1920 s - that is, the focus on efficiency in citybuilding, the strong belief in the ability of technology to solve social problems, and the reliance on the master planner/expert to accomplish a better world - CIAM also broke with past ideals in significant ways. This aspect of the evolution of urbanism was not immediately apparent. As Jane Jacobs analyzed things, Le Corbusier's Radiant City came directly out of Howard's Garden City, where the former was simply adapted to much higher densities. While it is true that superhighways, super-blocks and pedestrian separation had all been advocated prior to CIAM, the differences are also important.
There is no escaping that many urbanists of the early $20^{\text {th }}$ century approved of modernist urbanism initially. The affinity was based on a desire to be efficient and modern. The venerable planner John Nolen wrote a review of Le Corbusier's The City of Tomorrow and its Planning in which he stated that "The modern world needs a modern city. It needs something more like what Le Corbusier has proposed." 12 He supported Corbusier's call for demolition of "blight," standardization of commercial buildings, zoning to increase the amount of space required around buildings, and, in general, the need to "combat" "habit and convention" that did not move by "logic and reason."

Yet there were key differences between the original conceptions of urbanism postulated at the start of the century (by people like Nolen) and the modernist urbanism of CIAM. For one thing, early $20^{\text {th }}$ century urbanists were suspicious of universalisms. Raymond Unwin argued for the need to consider not whether the formal or the informal is desired, but whether the "requirements of the case" and the "conditions of the site" had been thoroughly weighed. ${ }^{13}$ One of Unwin's favorite quotes was by the painter Jean-Francois Millet, who wrote: "The beautiful is that which is in place."14 John Nolen spoke in similar terms, and defined beauty as "fitness and appropriateness." Nolen wrote in 1908: "We have curved streets where they should be straight, straight streets where they should be curved, narrow streets where they should be broad, occasionally broad streets where they should be narrow." 15

The focus on collectivism, the merger of art and science, and the belief that architecture and urbanism could create social cohesion were values shared by the early urbanists and the later modernists. But CIAM transformed these notions is ways that were so ungrounded that it became a fundamentally different approach. Le Corbusier's belief that Taylorist mass production strategies were "natural" and therefore "above politics" stands in contrast to Progressive Era urbanists who were much more humanistic. Patrick Geddes and Raymond Unwin sought individual liberation through collective enterprise, something CIAM arrived at through a different logic - the logic of arranging and combining the material elements of urbanism as if they were abstract, geometric shapes. The 
statement on the title page of La Ville Radiuse by Le Corbusier that "plans are the rational and poetic monument set up in the midst of contingencies" gives an indication of the level of abstraction that was transforming this new conceptualization of urbanism into something very different from that of Patrick Geddes, Raymond Unwin, or even Daniel Burnham. ${ }^{16}$

Jane Jacobs contended that urban planners who were later aghast at Le Corbusier's brutal towers in a park were only getting what they deserved, which was essentially a more intense interpretation of the 1920's city for the automobile. Garden city advocates had to admit that they had already severed the building line from the street line in the early decades of the $20^{\text {th }}$ century. But they had never intended the separation to go so far. Some, like Lewis Mumford, recognized that the proposal to organize cities according to separate functions was suspect. In a letter rejecting Sert's invitation to write a forward to the CIAM manifesto, Can Our Cities Survive?, Mumford asks, "what of the political, educational, and cultural functions of the city: what of the part played by the disposition and plan of the buildings concerned with these functions in the whole evolution of the city design."17

CIAM's rejection of history was another significant departure. Le Corbusier had famously recommended the destruction of Paris and then Manhattan given their accretions of the past. In their place was to be a new kind of urbanism that had little connection to regional culture, material, or building type. The detached, sterilized scheme was well suited to a highly organized mass society, but unlikely to be embraced by urbanists of the Garden City (advocating for Ruskin-like informality) or City Beautiful (advocating classicism) variety. ${ }^{18}$ The issue of maintaining the individuality of every city was stated repeatedly as a means of raising the quality of civic life by extolling a region's history and natural beauty. Raymond Unwin, for example, referred to the individuality of urban character as "the poetry of its existence." 19 John Nolen wrote of the need to instill "love and pride in local traditions and local ideals," 20 which rested on his belief that "Civic art furnishes the most available means to express these local customs." 21

Sometimes connections between modernist and other urbanist proposals are made on the basis of scale. Largescale plans for urbanism are said to be related to each other by similarity of land acquisition and creative financing schemes. It is on this basis that Ebenezer Howard has been linked to CIAM, ${ }^{22}$ or the modernist Catherine Bauer is linked to the Garden City architect Raymond Unwin. ${ }^{23}$ Yet there were wide differences in urbanistic outcome. Howard advocated a community of 30,000 while Le Corbusier's was 3,000,000. There were superblocks with internal green spaces, but there was no requirement for functional separation, rejection of the street, or centralized density.

Modernist ideology supported the view that buildings did not have to be subordinated to the urban fabric. The difference between the modernist building, free floating in space, and the City Beautiful was significant if viewed in terms of the rules of traditional urban form, street and block arrangement, and the relationship between building and street. City Beautiful urbanists would have been concerned that their open spaces not become lifeless. Modernist planners seemed not to understand the crucial difference between visual open space and habitable open space, and thus became like sculptors working in an unencumbered sculpture garden. $^{24}$

Variety was not something modernists viewed positively. Small scale diversity was something to be avoided because it meant the loss of control and uniformity. Property limits and streets simply got in the way of large scale rehousing projects. This is why Unwin never became a modernist, and why Howard and Unwin would have hated collective living that stressed uniformity of style. Their interpretation of collectivity did not have to do with sameness. ${ }^{25}$

Again, it is this division between the traditional elements of urban form - street, block, square - and the CIAM conceptualization of form as high rise building set in green space that reveals a stark contrast in approach. The modernist rejection of figural space may have seemed reasonable on the surface: to free up more open, green space and let in more light and air, one could build at higher and higher densities and therefore occupy smaller and smaller land area. This could produce the "biologically important advantages" that Le Corbusier thought so important. ${ }^{26}$ But it was a narrower point of view than anything the earlier urbanists would have proposed. This was reflected in the fact that consideration of the third-dimension was limited to height, since "it is in admitting the element of height that efficacious provisions can be made for traffic needs and for the creation of open spaces for recreation or other purposes." 27 But, as Eric Mumford points out, this was a "fateful formulation" used to justify "vast numbers of high-rise slab projects built over the last seventy years around the world," 28 a development form CIAM's own members came to hate. 


\section{From Contradiction to Consensus: The Emerging Clarity of $21^{\text {st }}$ Century Urbanism}

By mid-century, the ill-effects of CIAM's approach to urbanism were becoming the subject of popular criticism. Jane Jacobs was the most forceful, but there were many others. There were proclamations of the death of modernism with its "blueprint for placelessness" and "centralized corporate decisionmaking." ${ }^{29}$ There was recognition of the need to return to, as Christopher Tunnard wrote in 1953 in The City of Man, a place of "memory, hope and visual pleasure."30 Trying to re-establish the "experience of place" became the cause of regionalism, historicism, townscape, and the legibility of Kevin Lynch. Ecologists and social scientists also weighed in with strong critiques of the Modern Movement in architecture. The ecologists based their critique on the failure of modernism to understand place and natural ecology, and the social scientists for attempting to socially engineer humankind.

At the beginning of a new century, we have in some ways come full circle. In terms of arriving at a definition of good urbanism, the experience of the last century can be summarized as follows: early urbanists had a particular vision of urbanism that was humanistic, contextual, and integrative. Much of it did not reject the past, nor local tradition. When confronted with modernist urbanism in the 1920s, these earlier urbanists reworked their proposals in ways that both embraced and rejected the emergent ideology. They were drawn to the goals of efficiency and equity, but their long held views about the importance of place and human scale contrasted sharply with modernist applications.

From our perspective now, the merging of early urbanists and modernists as two sides of the same coin, as Jane Jacobs proposed, seems to miss something. What seems clearer now is that there were two distinct trends. To a large degree, the interaction between these trends has now evolved to the point where there is a high degree of consensus - among planners, architects, and urban proponents in general - about what good vs. bad urbanism is. The current definition is based on the urbanist ideals of the early $20^{\text {th }}$ century to some extent, but not in any purified, retrogressive sense. The collision with modernist urbanism, and the resulting backlash that occurred, has fostered a clearer, sharper vision of what good urbanism is supposed to be. The contrast has given us the ability to see the main tenets of urbanism - good and bad - in a clearer light.

We need to maintain a strong connection to past conceptions of urbanism. Little is gained by dismissing past ideals and forging ahead with what is believed to be a clean slate of concepts. It obscures any sense that our ability to define good urbanism has progressed, that there is now emerging a strong consensus that could potentially enable a more powerful effect on settlement form.

\section{References}

1. Talen, Emily. 2005. New Urbanism and American Planning: The Conflict of Cultures. London: Routledge.

2. For a detailed discussion of CIAM, see Mumford, Eric. 2000. The CIAM Discourse on Urbanism, 19281960. Cambridge: MIT Press.

3. in Mumford, 2000, p. 87.

4. Giedion in Sert, Jose Luis. 1944. Can Our Cities Survive? An ABC of Urban Problems, Their Analysis, Their Solutions. Cambridge: Harvard University Press, p. xi.

5. See Fishman, Robert. 1977. Urban Utopias in the Twentieth Century: Ebenezer Howard, Frank Lloyd Wright, and Le Corbusier. New York: Basic Books.

6. Jencks, Charles. 1987. Modern Movements in Architecture. New York: Penguin Books, p. 300.

7. Jacobs, Jane. 1961. The Death and Life of Great American Cities. New York: Vintage Books, p. 24; Wilson, William H. 1989. The City Beautiful Movement. Baltimore, MD: Johns Hopkins University Press.p. 79.

8. Scott, Mel. 1969. American City Planning Since 1890. Berkeley, CA: University of California Press, p. 108.

9. Boyer, M. Christine. 1983. Dreaming the Rational City: the Myth of American City Planning. Cambridge: MIT Press, p. 274-75.

10. cited in Jacobs, Jane. 1961, p. 173.

11. Lovelace, Eldridge. 1992. Harland Bartholomew: His Contributions to American Urban Planning. Urbana, IL: University of Illinois, p. 37.

12. Nolen, John. Undated. Review of The City of Tomorrow and its Planning. By Charles-Edouard Jeanneret Le Corbusier. Translated from the $9^{\text {th }}$ edition of Urbanisme, with an introduction by Frederick Etchells. New York: Payson and Clarke, Ltd. From the Rare and Manuscript Collections, Carl A. Kroch Library, Cornell University, Ithaca, NY. p. 9. 
13. Unwin, Raymond. 1909. Town Planning in Practice: An Introduction to the Art of Designing Cities and Suburbs. London: T. Fisher Unwin, p. 138.

14. Creese, Walter L. 1967. The Legacy of Raymond Unwin: A Human Pattern for Planning. Cambridge, MA: The MIT Press, p. 40.

15. Nolen, John. 1908. "The Philosophy of City Planning." From the Rare and Manuscript Collections, Carl A. Kroch Library, Cornell University, Ithaca, NY, p. $2 ;$ p. 7.

16. cited in Mumford, 2000, p. 20; p. 49.

17. in Mumford, 2000, p. 133.

18. Banik-Schweitzer, Renate. 1999. Urban Visions, Plans, and Projects, 1890-1937. In Eve Blau and Monika Platzer, eds., Shaping the Great City: Modern Architecture in Central Europe, 1890-1937. Munich: Prestel. Pp. 58-72; p. 68.

19. Unwin, 1909, p. 146.

20. Nolen, John. 1909. "City Planning and the Civic Spirit." Lecture presented at the annual meeting of the American Civic Association, held at Cincinnati, November 16, 1909. From the Rare and Manuscript Collections, Carl A. Kroch Library, Cornell University, Ithaca, NY, p. 74.
21. from Scott, 1969 , p. 98.

22. Mumford, 2000.

23. Birch, Eugenie Ladner. 1983. Radburn and the American Planning Movement: The Persistence of an Idea. In Donald A. Krueckeberg, ed., Introduction to Planning History in the United States. New Brunswick, NJ: The Center for Urban Policy Research. Pps. 122-151; p. 323.

24. Newman, Oscar. 1972. Defensible Space: Crime Prevention Through Urban Design. New York: Simon \& Schuster.

25. See Peter Hall, 2004, Cities of Tomorrow, on this point.

26. cited in Mumford, 2000, p. 38.

27. Sert, 1944, p. 150.

28. Mumford, 2000, p. 38.

29. Ley, David. 1987. Styles of the times: Liberal and neo-conservative landscapes in inner Vancouver, 1968-86. Journal of Historical Geography 13, 1: 4056.

30. Tunnard, Christopher. 1953. The City of Man. New York: Charles Scribner's Sons, p. 384. 